\title{
PERSISTENCE OF SOME INSECTICIDES ON POLYETHELENE AND JUTE SACKS IN THE PROTECTION OF STORED WHEAT GRAIN AGAINST SOME STORED PRODUCT INSECTS
}

\author{
ZEWAR, MAWAHEB M. AND SANAA M. MAHGOUB \\ Plant protection research institute.ARC, Dokki. Egypt \\ (Manuscript received 5 September 2011)

\begin{abstract}
Dusting of polyethelen and jute sacks with Fenitrotion $1 \%$, Deltamethrin $1 \%$ and Bendiocarb $0.1 \%$ at the rate of 500 and 1300 $\mathrm{mg} / \mathrm{m}^{2}$ using Manual duster were carried out and stored in open shaunas up to 3 months in Ismailia and Gharbia governorates to evaluate the persistence against 4test insects (sitophilus oryzae(L.), Rhizopertha dominica(F.), Trogoderma granarium Everst and Tribolium castaneum (Herbst) adults. Considering pest mortality and germination. Results indicated that :-
\end{abstract}

- Tested insecticides were more persistence on polyethelen sacks than on Jute fabrics.

- Protection of stored wheat graing was more succeesful in Ismailia governorate than in Gharbia governorate at all storage periods and tested doses.

- Fenitrothion insecticide was more effective in moiety in killing tested insects on the two doses and experimental sacks at the two governorates. It gave complete protection (100\%mortality)

With high dose $\left(1300 \mathrm{mg} / \mathrm{m}^{2}\right)$ using polyethelen sacks for the three storage months, in Ismailia governorate However, gradual decrease in protection was occured when using Jute sacks (70/mortality)

- Residual efficiency of bendiocarb at $1300 \mathrm{mg} / \mathrm{m}^{2}$ was the least, it gave a complete protection of grain ( $100 \%$ mortality) for one month only in the two governorate, and decreased after 2 and 3 on months in polyethelen sacks showing 81\%,70\% and $79 \%, 74 \%$ in Ismailia and Gharbia governorates, respectively whereas, sharp decrease of efficiency was detected with Jute sacks, it gave $19 \%$ and $12 \%$ mortality after 3 months in the tested governorate, respectively .

- Deltamethrin insecticide gave intermediate in its efficiency on both tested sacks and doses in the two governorates .

- The treatments did not impair the germination of seeds under various treatments at the two tested governorates. 


\section{INTRODUCTION}

It is common practice to apply insecticides on sacks of commodities to prevent re-infestation after fumigation. The effectiveness of insecticides treatments has been studied on jute bags in the laboratory and field by McFarlane (1961), and El-Rafie et al (1974) .

Many countries place restrictions on the permitted type and the amount of insecticide used for the spraying of commodities in bags in order to prevent the build up of residues to undesirable levels (wabley and Kenneth 1980).

In Egypt, however very little work has been carried out on this area and no data on long term on storage of grains or the comparative effectiveness of insecticides applied are available.

It is also, important to compare the persistence and effectiveness of insecticides on two surfaces and to determine which type of insecticide is most suitable for dusting (polyethelene or jute sacks) under laboratory and field conditions in open, shounas in both Ismailia and Gharbia governorates.

\section{MATERIALS AND METHODS}

\section{1 - Experimented technique :}

Three insecticides Dethamethrin 1\%, Fenitrothion $0.1 \%$ and Bendiocarb $1 \%$ (dust) were used, at doses of 500 and $1300 \mathrm{mg} / \mathrm{m}^{2}$. Small jute and woven polyethelen sacks $(25 \times 18 \mathrm{~cm})$ were used Samples of $500 \mathrm{gr}$. of untreated wheat grain were packed in each sack then the two open ends were closed tightly to prevent any external infestation. Using an manual duster, the outer surface of each sack was dusted with each insecticide and each dose. similar untreated samples of sacks were used as control. Each treatment was replicated 10 times. Storage periods were three in months begin from July to October (2010). Sacks samples of every storage month were kept in Carton boxes $40 \times 25 \times 9 \mathrm{~cm}$ in dimention.

Hundered adults of each insect species $S$. oryzae, R. dominica, T. granarium and $T$. castaneum (2-3 weeks old) were seurtered on the outer surface of the sacks and the carton box tightly covered with mosilen cloths. The boxes were left for three days then inspection of mortality insect was recorded.

Sacks were stored at two open storage conditions, the first at Ismailia and the second at Gharbia governorate. At the end of storage period, tests were recorded for each insecticide, dose, type of sack at each shauna for each treated surface Percentage of mortalities of the four tested insects after exposure times were corrected for control response by Abbott's formula (Abbott, 1925). 


\section{Germination test}

At the end of storage period (after three months) germination test were occurred. 100 seeds of stored wheat grain from each treatment together with control were replicated four times and placed in Petri dish lined with two layers cotton layer and filter paper layer, both were soaked with water . after five days, the observed percentage of germination was recorded in each petri dish.

\section{RESULTS AND DISCUSSION}

\section{Ismailia governorate.}

\section{A- Residual efficiency of Fenitrothion:-}

data in table 1 clearly shows that, dose of $500 \mathrm{mg} / \mathrm{m}^{2}$ prevent the penetration of tested insects for one month of storage and decrease slightly in the third month when use polyethelen sacks. The mortality percentage was $100 \% 95 \%$ and $90 \%$ also, jute sacks gave only one month protection followed by pronounced sharp decreas in efficiency for the tested insects showing $100 \%, 60 \%$ and $44 \%$ respectively.

Complete protection was occurred with the higher dose $\left(1300 \mathrm{mg} / \mathrm{m}^{2}\right)$ using polyethelen sacks for the three storage months while, a gradual decrease in protection was occurred when using jute sacks i-e 93,84 and $70 \%$ in the three tested months, respectively. The obtained results are agree with Webley and kilminster (1980) who found that tested insecticides were found to have a much persistence on polypropylene than on jute sacks.

\section{B- Residual efficiency of Deltamethrin :-}

Table 1 revealed that polyethelen sacks at dose of $1300 \mathrm{mg} / \mathrm{m}^{2}$ gave a complete protection (100\% mortality) after one month of storage, meanwhile it gave $80 \%$ protetion using jute sacks. Aradual protection of $94 \%$ and $95 \%$ was occurred with polyethelen after 2 and 3 month of storage respectively. Meanwhile respectively, jute sacks has a sharp decrease in mortality after 2 and 3 months (59\% and $45 \%$ mortality).

\section{C - Residual efficiency of Bendiocarb:-}

Table 1 revealed that After one month of storage, complete protection of insect mortalities on treated polyethelen sacks was occured for both tested doses. After 2 and 3 months of storage, gradual decrease of mortalities was detected at 500 and $1300 \mathrm{mg} / \mathrm{m}^{2}$ showing $64 \%, 48 \%$ and $81 \%, 70 \%$ respectively. Sharp decrease of efficiency was detected with Jute sack i.e. $63 \%, 31 \%, 10 \%$ and $70 \%, 44 \%$ and $19 \%$ with dose of $500 \mathrm{mg} / \mathrm{m}^{2}$ and $1300 \mathrm{mg} / \mathrm{m}^{2}$ respectively. These results agree with Manoj et al (2003) they revealed that tested insecticides as a surface treatments will provide long-term protection up to 40 weeks against infestation by three species of stored grain insects. 


\section{2) Gharbia governorate.}

\section{A - residual efficiency of Fenitrothion $F$ :}

Results in table 2 indicated that Fenitrothion on polyethelen fabrics gave a complete protection ( $100 \%$ mortality) on wheat grain sacks for only one month in both tested doses, then, the mortality decreased up to $89 \%$ after three months at the highest dose $\left(1300 \mathrm{mg} / \mathrm{m}^{2}\right)$ whereas, the activity on Jute sacks was less effective in killing tested insects. The insecticide had a sharp decrease up to $68 \%$, and $36 \%$ after three months at 1300 and $500 \mathrm{mg} / \mathrm{m}^{2}$ respectively.

The above mentioned results are disagree with the results from barakat et al (1987), they reported that treatment of commercial bags with permethrin and chloropyrifos methyl preventing the infestation of wheat in Jute sack with Tribolium confusum

\section{B - Residual efficiency of Deltamethin :}

In case of Deltamethrin, it failed to gave complete protection on polyethlene and Jute fabrics and deteriorated up to $85 \%$ after three months at the highest dose. The corresponding data on Jute fabrics were $39 \%$.

\section{C - Residual efficiency of bendiocarb :-}

Results showed also that, after three months, the activity of Bendiocarb was greater ( $100 \%$ mortality) on polyethelen and then, it had a sharp declind up to $74 \%$ at the highest dose, whereas, the deterioration was faster up to $12 \%$ in Jute fabrics after three months.

It can be concluded from the present studies that tested insecticides were more persistent on polyethelen sacks than on Jute fabrics, Due to that, no penetration of insecticide through polyethelen surface, residue can not be expected in the enclosed grain. Thus treatment of polyethelen fabrics with insecticides against infestation will proved a useful protective technique.

These results are in agreement with Mahgoub and Elsisi (1991) who found that some oils were highly persistence after treatment of some surfaces against $\underline{\mathbf{s}}$. oryzae adults especially on non porous surfaces.

On the other hand, results revealed that, storage in Ismailia governorate was succeeded in protection wheat grain than in Gharbia governorate at all storage periods and tested doses.

The data on germination is presented in table (3). From the results it was showed that the treatment did not impair the germination of seeds stored under various treatments. 
Table 1. Effect of surface treatment of polyethelen and Jute sacks with insecticides on the protection of stored what grain from insect infestation at Ismailia governorate.

\begin{tabular}{|c|c|c|c|c|c|c|c|c|}
\hline \multirow{3}{*}{$\begin{array}{c}\text { Tested } \\
\text { insecticides }\end{array}$} & \multirow[t]{3}{*}{$\begin{array}{l}\text { Dose } \\
\mathrm{mg} / \mathrm{m}^{2}\end{array}$} & \multirow[t]{3}{*}{ Tested insects } & \multicolumn{6}{|c|}{$\begin{array}{l}\text { Corrected mortality \% after indicated } \\
\text { (months) }\end{array}$} \\
\hline & & & \multicolumn{3}{|c|}{ Polyethelen sacks } & \multicolumn{3}{|c|}{ Jute sacks } \\
\hline & & & 1 & 2 & 3 & 1 & 2 & 3 \\
\hline $\begin{array}{c}\text { Fenitrothio } \\
\mathrm{n}\end{array}$ & 500 & S. oryzae & 100 & 100 & 100 & 100 & 75 & 60 \\
\hline \multirow[t]{9}{*}{ (1\% Dust) } & & R. dominica & 100 & 100 & 90 & 100 & 65 & 45 \\
\hline & & T. granarium & 100 & 90 & 80 & 100 & 50 & 40 \\
\hline & & T. castaneum & 100 & 90 & 90 & 100 & 50 & 30 \\
\hline & mean & & 100 & 95 & 90 & 100 & 60 & 44 \\
\hline & 1300 & S. oryzae & 100 & 100 & 100 & 100 & 100 & 70 \\
\hline & & R. dominica & $"$ & $"$ & " & 90 & 80 & 65 \\
\hline & & T. granarium & $"$ & $"$ & $"$ & 90 & 75 & 70 \\
\hline & & T. castaneum & $"$ & $"$ & $"$ & 90 & 80 & 75 \\
\hline & mean & & 100 & 100 & 100 & 93 & 84 & 70 \\
\hline $\begin{array}{l}\text { Deltamethr } \\
\text { in }\end{array}$ & 500 & S. oryzae & 100 & 97 & 95 & 90 & 50 & 40 \\
\hline \multirow[t]{9}{*}{ (1\% Dust) } & & R. dominica & 85 & 80 & 75 & 60 & 40 & 25 \\
\hline & & T. granarium & 85 & 85 & 80 & 40 & 35 & 30 \\
\hline & & T. castaneum & 85 & 70 & 70 & 50 & 20 & 10 \\
\hline & mean & & 87 & 78 & 80 & 60 & 36 & 26 \\
\hline & 1300 & S. oryzae & 100 & 100 & 100 & 95 & 80 & 65 \\
\hline & & R. dominica & 100 & 100 & 100 & 80 & 60 & 45 \\
\hline & & T. granarium & 100 & 85 & 90 & 70 & 40 & 30 \\
\hline & & T. castaneun & 100 & 90 & 90 & 75 & 55 & 40 \\
\hline & mean & & 100 & 94 & 95 & 80 & 59 & 45 \\
\hline Bendiocarb & 500 & S. oryzae & 100 & 80 & 60 & 80 & 40 & 30 \\
\hline \multirow[t]{9}{*}{ (1\% Dust) } & & R. dominica & 100 & 70 & 60 & 70 & 30 & 10 \\
\hline & & T.granarium & 100 & 55 & 30 & 40 & 30 & 0.0 \\
\hline & & T. castaneum & 100 & 50 & 40 & 60 & 25 & 0.0 \\
\hline & mean & & 100 & 64 & 48 & 63 & 31 & 10 \\
\hline & 1300 & S. oryzae & 100 & 95 & 80 & 90 & 90 & 75 \\
\hline & & R. dominica & 100 & 80 & 75 & 80 & 55 & 0.0 \\
\hline & & T. granarium & 100 & 75 & 65 & 50 & 30 & 0.0 \\
\hline & & T. castaneum & 100 & 70 & 60 & 60 & 55 & 0.0 \\
\hline & mean & & 100 & 81 & 70 & 70 & 44 & 19 \\
\hline
\end{tabular}


Table 2. Effect of surface treatment of polythelen and Jute sacks on the protection of stored grain from insect infestation at Gharbia governorate.

\begin{tabular}{|c|c|c|c|c|c|c|c|c|}
\hline \multirow{3}{*}{$\begin{array}{c}\text { Tested } \\
\text { insecticides }\end{array}$} & \multirow[t]{3}{*}{$\begin{array}{l}\text { Dose } \\
\mathrm{mg} / \mathrm{m}^{2}\end{array}$} & \multirow[t]{3}{*}{ Tested insects } & \multicolumn{6}{|c|}{$\begin{array}{l}\text { Corrected mortality \% after indicated } \\
\text { (months) }\end{array}$} \\
\hline & & & \multicolumn{3}{|c|}{ Polyethelen sacks } & \multicolumn{3}{|c|}{ Jute sacks } \\
\hline & & & 1 & 2 & 3 & 1 & 2 & 3 \\
\hline $\begin{array}{l}\text { Fenitrothio } \\
\mathrm{n}\end{array}$ & 500 & S. oryzae & 100 & 100 & 100 & 85 & 65 & 50 \\
\hline \multirow[t]{9}{*}{ (1\% Dust) } & & R. dominica & 100 & 80 & 70 & 95 & 60 & 40 \\
\hline & & T.granarium & 100 & 80 & 75 & 100 & 40 & 25 \\
\hline & & T. castaneum & 100 & 80 & 75 & 95 & 50 & 30 \\
\hline & mean & & 100 & 85 & 80 & 94 & 54 & 36 \\
\hline & 1300 & S. oryzae & 100 & 100 & 100 & 100 & 95 & 75 \\
\hline & & R. dominica & 100 & 90 & 85 & 100 & 80 & 70 \\
\hline & & T. granarium & 100 & 95 & 90 & 100 & 75 & 60 \\
\hline & & T. castaneum & 100 & 83 & 80 & 90 & 70 & 65 \\
\hline & mean & & 100 & 92 & 89 & 98 & 80 & 68 \\
\hline $\begin{array}{l}\text { Deltamethr } \\
\text { in }\end{array}$ & 500 & S. oryzae & 100 & 95 & 90 & 65 & 50 & 30 \\
\hline \multirow[t]{9}{*}{ (1\% Dust) } & & R. dominica & 80 & 70 & 65 & 55 & 45 & 20 \\
\hline & & T. granarium & 70 & 60 & 60 & 65 & 0.0 & 0.0 \\
\hline & & T. castaneum & 79 & 79 & 75 & 60 & 0.0 & 0.0 \\
\hline & mean & & 80 & 76 & 72 & 61 & 24 & 12 \\
\hline & 1300 & S. oryzae & 100 & 100 & 85 & 90 & 70 & 55 \\
\hline & & R. dominica & 100 & 90 & 85 & 75 & 55 & 35 \\
\hline & & T. granarium & 96 & 90 & 90 & 60 & 45 & 30 \\
\hline & & T. castaneum & 90 & 85 & 80 & 65 & 40 & 35 \\
\hline & mean & & 97 & 91 & 85 & 73 & 53 & 39 \\
\hline Bendiocarb & 500 & S.oryzae & 85 & 65 & 60 & 80 & 25 & 0.0 \\
\hline \multirow{9}{*}{$\begin{array}{l}\text { (0.1\% } \\
\text { Dust) }\end{array}$} & & R.dominica & 85 & 55 & 55 & 60 & 25 & 0.0 \\
\hline & & T.granarium & 70 & 78 & 65 & 25 & 0.0 & 0.0 \\
\hline & & T.castaneum & 75 & 60 & 65 & 25 & 0.0 & 0.0 \\
\hline & mean & & 79 & 64 & 61 & 47 & 12 & 0.0 \\
\hline & 1300 & S. oryzae & 100 & 80 & 75 & 65 & 60 & 50 \\
\hline & & R. dominica & 100 & 75 & 70 & 55 & 45 & 0.0 \\
\hline & & T. granarium & 100 & 75 & 70 & 65 & 35 & 0.0 \\
\hline & & T. castaneum & 100 & 85 & 80 & 60 & 45 & 0.0 \\
\hline & mean & & 100 & 79 & 74 & 61 & 46 & 12 \\
\hline
\end{tabular}


Table 3. Efficiency of polyethelen and Jute sacks treated with insecticides on germination of wheat grains at Ismailia and Gharbia governorates at the end of storage period (after three months)

\begin{tabular}{|c|c|c|c|c|c|}
\hline \multirow[t]{3}{*}{ Tested insecticides } & \multirow{3}{*}{$\begin{array}{l}\text { Dose } \\
\left(\mathrm{mg} / \mathrm{m}^{2}\right)\end{array}$} & \multicolumn{4}{|c|}{$\begin{array}{c}\% \text { Germination percentage } \\
\text { at different sacks }\end{array}$} \\
\hline & & \multicolumn{2}{|c|}{ Ismailia } & \multicolumn{2}{|c|}{ Gharbia } \\
\hline & & $\begin{array}{c}\text { Polyethlene } \\
\text { sacks }\end{array}$ & $\begin{array}{l}\text { Jute } \\
\text { sacks }\end{array}$ & $\begin{array}{c}\text { Polyethlene } \\
\text { sacks }\end{array}$ & $\begin{array}{l}\text { Jute } \\
\text { sacks }\end{array}$ \\
\hline \multirow{2}{*}{ Fenitrthion } & 500 & 96 & 96 & 94 & 95 \\
\hline & 1300 & 97 & 95 & 97 & 96 \\
\hline \multirow{2}{*}{ Deltamethrin } & 500 & 95 & 96 & 97 & 94 \\
\hline & 1300 & 96 & 97 & 95 & 96 \\
\hline \multirow{2}{*}{ Bendiocarb } & 500 & 95 & 95 & 95 & 95 \\
\hline & 1300 & 94 & 93 & 96 & 96 \\
\hline \multirow[t]{2}{*}{ Control } & 500 & 97 & 95 & 96 & 97 \\
\hline & 1300 & 96 & 95 & 97 & 96 \\
\hline
\end{tabular}




\section{REFERENCES}

1. Abbott W. S. 1925. A method of computing the effectiveness of an insecticide. J. econ. Ent., 18: 265-267.

2. Barakat, A. A., P. khan, and A.M. abd ul karim. 1987. The persistence and activity of permethrin and chloro pyrifos-methyl sprays on Jute and worn polypropylene bags. J. stored prod. Res Vol 23, No 2 : 85-90.

3. El-Rafie, M. S., A. H. Kamel and M. M. Zewar. 1974. The residual efficiency of DDT and malathion deposits in treated cloth bags in the protection of stored wheat grain and flour from infestation with certain pests under winter and summer condition. Agric. Res. Rev. Vol 53, 87-99

4. Mahgoub. S. M. and A. El-sisi 1991. Evaluation the insecticidal efficiency of some Egyptian petroleum oil fraction. Egypt. J. Agric Vo. 73: 973-980

5. Manoj. K. Nayak, Patrick . J. Colling and Kopittke 2003.

6. Residual toxicities and persistence of organophos phate phorus insecticides mixed with Carbaryl as structural treatments against three liposcelidid psocid species infesting stored grain. J.of stored products Res, Vol 39, issue 4, 343-353.

7. Mc. Fariane, J. A. 1961. Malathion water-dispersible Powder for the protection of bagged foodstuffs from insect infestation. Trop. Sci. 3: 114-126.

8. Webley, D. J. and K. M. Kilminster. 1980. The persistence of insecticide spray deposits on woven polypropylene and Jute packing. Pestic. Sci. 11: 667-673. 


\title{
بقاء بعض المبيدات علي أكيـاس البولي ايثلين والجوت لحمايـة القــح المخزن ضد بعض حشرات الحبوب المخزونة الئة
}

\author{
مواهب محمود زيوار سناء محمود محجوب \\ معهر بحوث وقاية النباتات - مركز البحوث الزراعية ـ دقى - جيزة - مصر
}

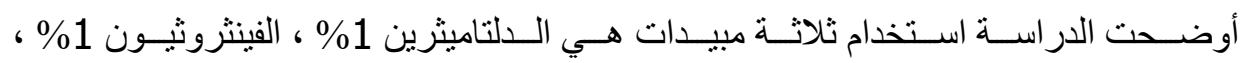

البنديوكارب 0.1\% علي صورة مسحوق وذللك لمعاملة سطح نو عين من أكياس تخزين القمح وهي أكياس

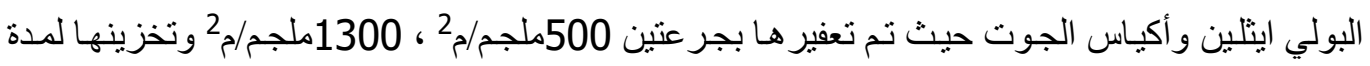

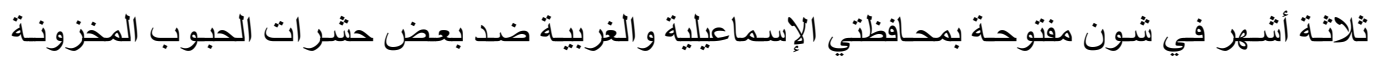

(سوسة الأرز ، ثاقبة الحبوب الصغرى ، خنفساء الصعيد ، خنفساء الدقيق الكستنائية)

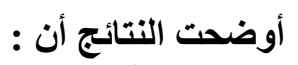

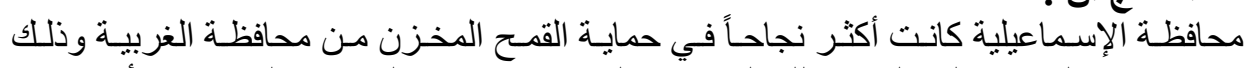

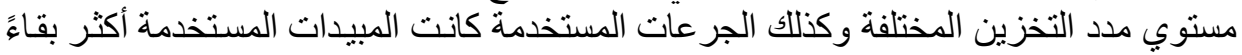

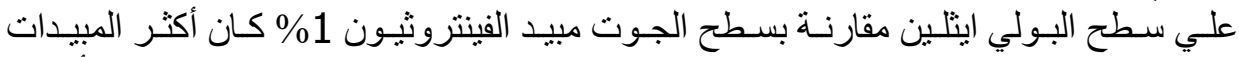

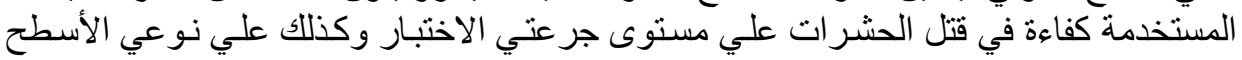

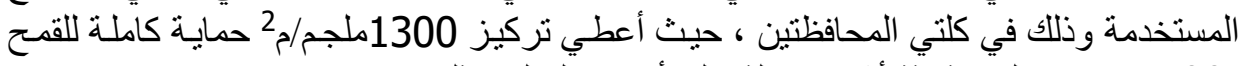

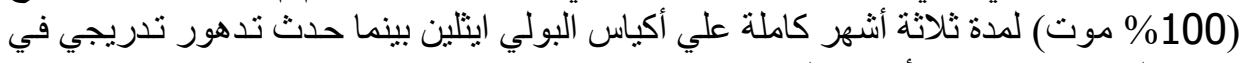

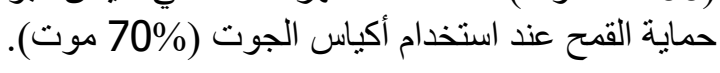

مبيد البنديوكارب كان أقل المبيدات المستخدمة كفاءةً وبقاءً علي أسطح الاختبار حبث أعطي

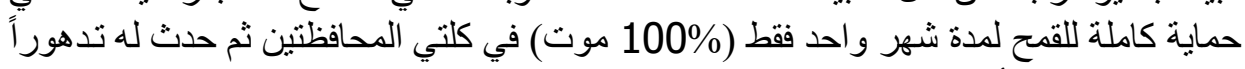

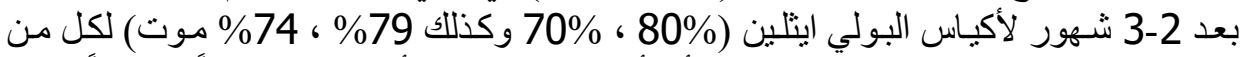

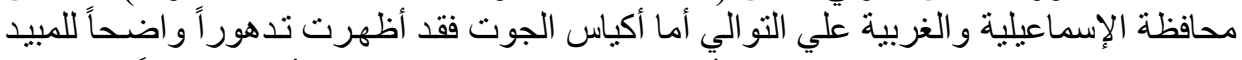

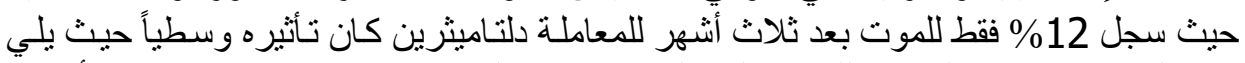

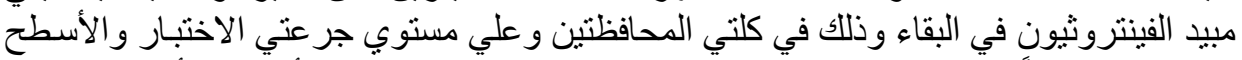

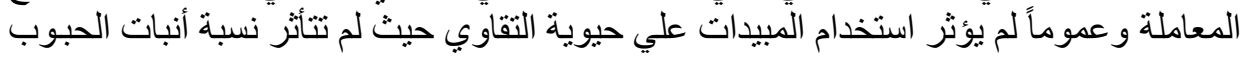

